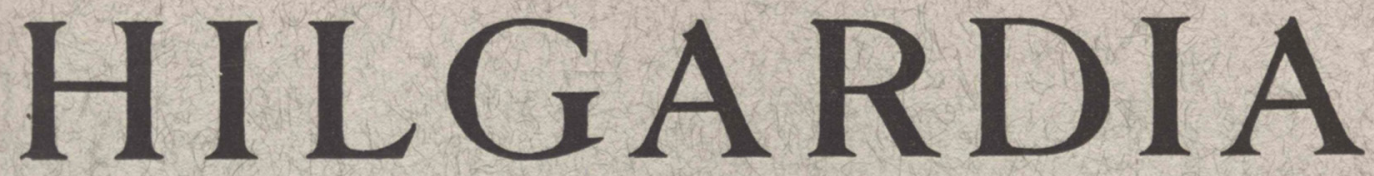

A Journal of Agricultural Science Published by the California Agricultural Experiment Station

\title{
ANATOMY OF BARK OF BUD UNION, TRUNK, AND ROOTS OF QUICK-DECLINE-AFFECTED SWEET ORANGE TREES ON SOUR ORANGE ROOTSTOCK HENRY SCHNEIDER
}

\section{CONDITION OF PHLOEM OF SOUR ORANGE TREE TRUNK IN WINTER}

HENRY SCHNEIDER

EFFECT OF TRUNK GIRDLING ON PHLOEM OF TRUNK OF SWEET ORANGE TREES ON SOUR ORANGE ROOTSTOCK HENRY SCHNEIDER 


\section{ANATOMY OF BARK OF BUD UNION, TRUNK, AND ROOTS ...}

This paper concerns the sequence of anatomical changes occurring in sweet orange trees on sour orange rootstock after infection by quick decline. The primary symptom is necrosis of sieve tubes below the bud union. This symptom is followed by degeneration of the older sieve tubes above the union, accelerated cambial activity, and other reactions of a secondary nature.

\section{CONDITION OF PHLOEM OF SOUR ORANGE TREE TRUNK IN WINTER}

Since the sieve tubes of the functioning phloem of sour orange stock of sweet orange trees become necrotic when the tree is affected by quick decline, the condition of the functioning phloem of the trunk of the healthy sour orange, both as a rootstock and as a seedling tree, especially in winter, was investigated.

Throughout the winter months trunks of healthy sour orange trees, and of sour orange rootstock under sweet orange tops, maintained a band of functioning phloem averaging about 500 microns in width. A ring of degenerating phloem external to this was either absent or as much as 100 microns wide. Occasionally, there were abnormally wide bands of degenerating phloem or bands of necrotic sieve tubes within the functioning phloem.

\section{EFFECT OF TRUNK GIRDLING ...}

... on phloem of trunk of sweet orange trees on sour orange rootstock was studied to discover whether the phloem above the removed bark reacts in the same way as that above the necrotic sieve tubes of the sour orange rootstock of quick-decline-affected trees. Sieve-tube degeneration above artificial girdling seems to be identical with that induced by girdling brought about naturally by necrosis of sieve tubes immediately below the union of a quick-decline tree.

\section{EXPLANATION OF TERMS}

Normal deterioration of sieve tubes after they have functioned for a year or two is termed degeneration. Abnormal deterioration of sieve tubes in diseased plants is termed necrosis. Which term should be used for some anomalous types of deterioration reported in these papers is open to question. The term induced degeneration has been applied to deterioration resulting from artificial or disease-produced girdling. For further clarification of terms, you are referred to the diagram presented on the inside of the back cover of this issue of Hilgardia. 


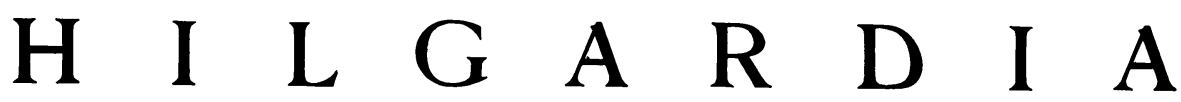

A Journal of Agricultural Science Published by

the California Agricultural Experiment Station

VoL. 22

FEBRUARY, 1954

No. 16

\section{ANATOMY OF BARK OF BUD UNION, TRUNK, AND ROOTS OF QUICK-DECLINE- AFFECTED SWEET ORANGE TREES ON SOUR ORANGE ROOTSTOCK ${ }^{1}$}

\section{HENRY SCHNEIDER ${ }^{2}$}

\section{INTRODUCTION}

BeCAUSE OF THE ECONOMIC IMPORTANCE of orange tree quick decline, the budunion anatomy of affected trees has been under study for a number of years. Semitechnical progress reports have been issued from time to time (Schneider, 1946, 1947), but no comprehensive technical article on the subject has been published. For this reason, a technical discussion of the anatomical changes that take place at the bud union and in the trunk and roots of orange trees under the influence of this disastrous disease is presented here.

The causal agent of quick decline is graft- and insect-transmissible and is presumably a virus (Fawcett and Wallace, 1946 ; Dickson, Flock, and Johnson, 1951). Only trees of sweet orange, Citrus sinensis (Linn.) Osbeck, on stock of sour orange, Citrus aurantium Linn., have declined naturally in commercial plantings in southern California, and only this combination is considered here. Apparently, the virus, or some material synthesized as a result of its presence in the scion, in some way causes sieve tubes and companion cells to become necrotic as it moves across the bud union in the translocation stream. This hypothesis is based on the observation that the injury first occurs in the 8 or 10 inches of tissue below the bud union and is most severe immediately below the union. The injury to the plant is similar to that caused by dilute eosin injection (Schumacher, 1930) and in many ways it resembles normal sieve-tube degeneration. Similar injury has been observed below the bud union of buckskin-virus-infected trees of sweet cherry, Prunus avium, on rootstock of Mahaleb cherry, Prunus mahaleb (Schneider, 1945). The anatomy of the healthy phloem of sweet orange and sour orange tree trunks is reported elsewhere (Schneider, 1952, 1954a).

${ }^{1}$ Paper No. 772, University of California Citrus Experiment Station, Riverside, California. Received for publication March 2, 1953.

${ }^{2}$ Associate Plant Pathologist in the Experiment Station, Riverside. 
Owing to the absence of specific external symptoms, the California State Department of Agriculture has used the anatomical symptoms as one method for diagnosing trees suspected of having quick decline (Altstatt, McClain, and Stout, 1948). Methods used for anatomical diagnoses have been described by Schneider, Wallace, and Dimitman (1950).

\section{REVIEW OF LITERATURE}

Quick decline of orange trees first attracted attention in 1939 in the CovinaAzusa area of southern California (Fawcett, 1946). In 1945, Halma, Smoyer, and Schwalm reported that the disease affected sweet orange trees on sour orange rootstock but not on sweet orange rootstock. In the same year, Fawcett (1945) reported the disappearance of starch from the rootstock of affected trees, as well as from trees artificially girdled. In some instances, in tests with iodine in potassium iodide, no color reactions were obtained in the wood below the bud union of quick-decline-diseased trees, whereas intense color reactions were obtained in the wood immediately above the bud union. In 1946, Schneider reported that sieve-tube necrosis occurred below the bud union of affected trees and that at the onset of the disease necrosis was confined to sieve-tube elements immediately below the union and appeared first in the younger sieve tubes. This suggested that the sieve tubes were being affected by something moving from the scion to the stock in the translocation stream. That same year Fawcett and Wallace (1946) reported evidence of the virus nature of the disease and its transmission by buds from affected sweet orange tops to healthy sweet orange tops on sour orange rootstock. Later, Dickson, Flock, and Johnson (1951) demonstrated transmission of the virus by Aphis gossypii.

Literature on diseases similar to or identical with quick decline in other parts of the world has already been reviewed (Batchelor and Webber, 1948; Bennett and Costa, 1949) and will not be repeated here. In South Africa and Java orange trees have never been successfully established on sour orange rootstock. In 1930, a disease similar to quick decline was found in Argentina. About 1937 it appeared in Brazil, where orange trees have been grown almost entirely on sour orange rootstock; there the disease is known as tristeza. The developmental pathological anatomy at the bud union of tristeza-affected and of quick-decline-affected mature trees appears to be the same (Schneider, Bitancourt, and Rossetti, 1947). The bud-union anatomy of trees infected by a disease which invaded Australia also seems to be the same (McAlpin et al., 1948). Veinclearing and other symptoms have recently been produced in West Indian (Mexican) limes upon inoculation with the quick-decline virus. This aspect of the disease has been described by Wallace (1951), who has compared symptoms produced in lime trees in the United States with those produced in lime trees in other countries after inoculation with similar viruses occurring in those countries.

Necrosis of sieve tubes with little or no pathological change in adjacent cells as a result of virus infections is known to occur only in potato plants affected by potato phloem necrosis (Artschwager, 1923), in peach and cherry affected by buckskin disease (Schneider, 1945), and in orange trees affected by quick decline. In potato phloem necrosis and in buckskin disease of peach 
and cherry, necrotic sieve tubes contain wound gum and stain red when treated with phloroglucinol and hydrochloric acid. Tests performed with these reagents on necrotic sieve tubes of orange trees affected by quick decline gave a negative reaction.

\section{MATERIALS AND METHODS}

The trees studied were 15-year-old Valencia orange scions on sour orange rootstock, growing in an orchard located between the cities of Covina and Azusa in southern California. Some of the trees were originally Washington Navel orange, but they had later been top-worked to Valencia orange and therefore had navel orange interstock. The trees not yet showing symptoms of quick decline were vigorous looking, and their trunks and bud unions were smooth. They were growing in a shallow layer of loamy sand underlaid by sand and gravel. When the study was begun in November, 1945, some of the trees were already naturally affected by quick decline. About half of the trees had previously been inoculated by budding but were not yet showing symptoms. Periodic collections of bark samples were made from trees while they were still healthy and, later, after top symptoms had appeared. Control trees were those obviously not affected in the Covina-Azusa plots and others in the Citrus Experiment Station plots at Riverside, which was outside the quickdecline area at the time.

Since none of the external symptoms of quick decline of sweet orange trees on sour orange rootstock are specific - that is, since similar decline (yellowing and loss of leaves and/or wilting) is caused by other factors-anatomical symptoms are used for diagnosis. Examinations have been made of several thousand sections of bark from trees suspected of having quick decline. These sections were prepared by members of the California State Department of Agriculture, who also determined, by the more time-consuming transmission tests, whether the trees actually had quick decline. Some quick-decline-affected bud unions from Florida and Louisiana also were studied.

Cross sections were made of bark samples taken 1 inch and 18 inches above and below the bud union, and radial sections were made of samples taken across the union. Collecting, sectioning, and staining methods used were those previously described (Schneider, 1952), except that in preparing slides for color photomicrography tannic acid was substituted for hematoxylin (method of Cheadle et al., 1953) (fig. 1, $A, B$ ), or Congo red was substituted for hematoxylin (fig. $1, D$ ), or lacmoid was used alone (fig. $1, C$ ).

\section{PATHOLOGICAL ANATOMY OF BARK AT BUD UNION OF MATURE TREES}

Initial Necrosis of Sour Orange Sieve Tubes. To determine where and how injury occurs at the onset of the disease, bark samples from apparently healthy trees were taken at 6 -week intervals across the bud union and 1 inch and 18 inches above and below the bud union. After the initial anatomical symptom of the disease had been recognized, progress of the injury was followed.

Necrosis of the younger sieve tubes and companion cells immediately below 

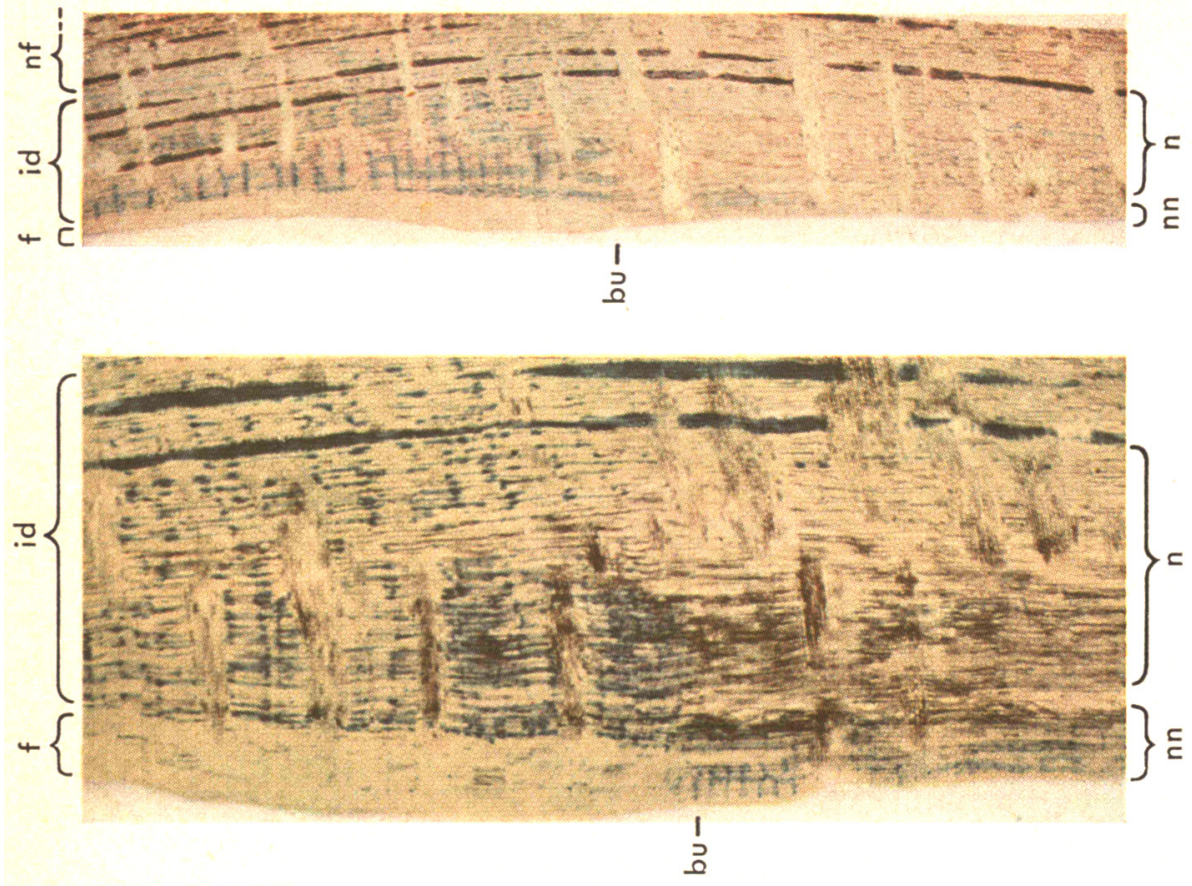

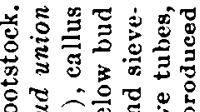

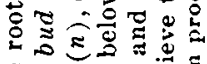

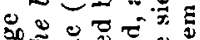

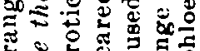

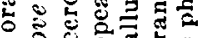
$\circ$ 造范

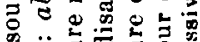

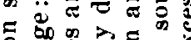
के के t

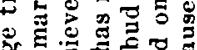
x.

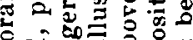
길 Ð

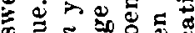
\%

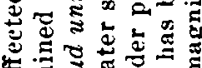

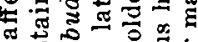

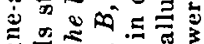
卷

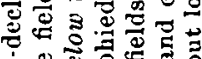
4

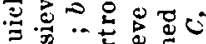

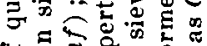

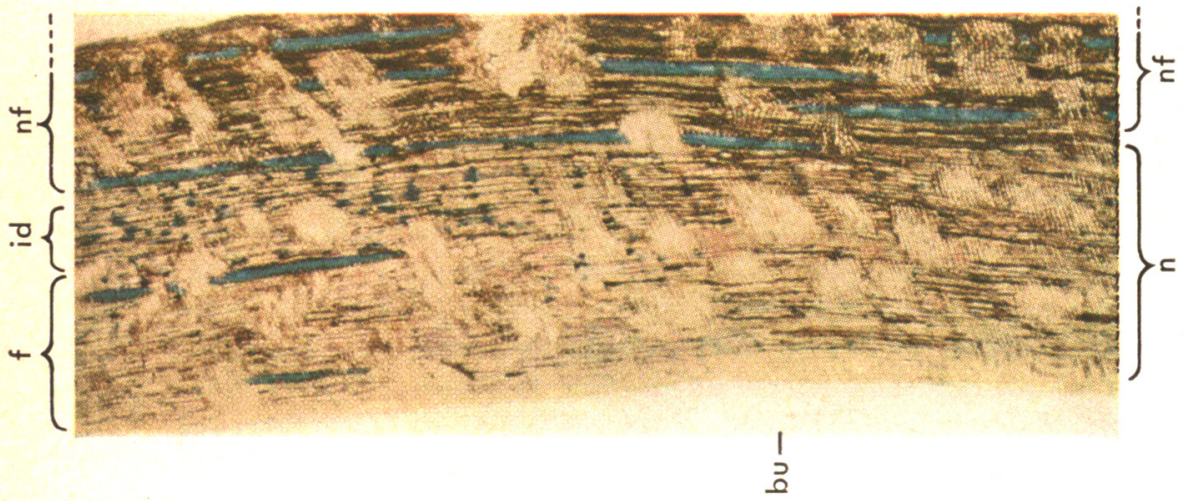

틍 ₹ 赵荡

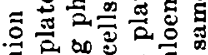
五

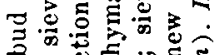
ฉ

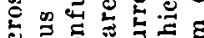

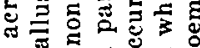

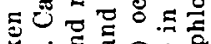
드 क्ष

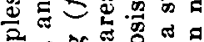

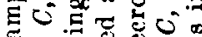

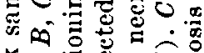

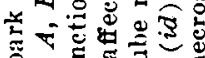

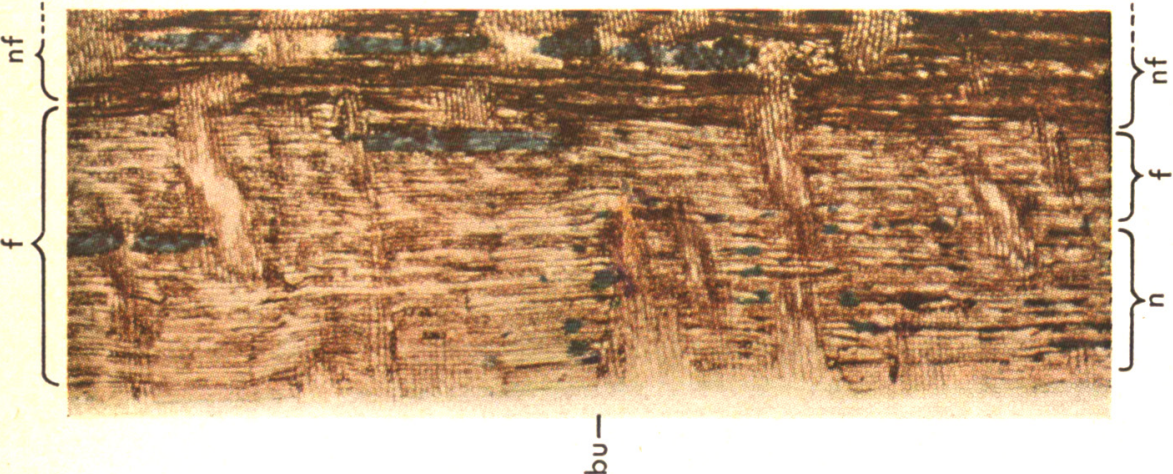
․․ㄹ

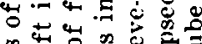

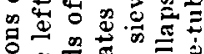

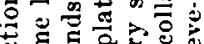
ष्ण.

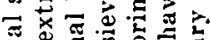

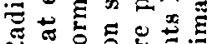

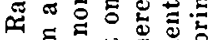
过

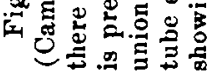



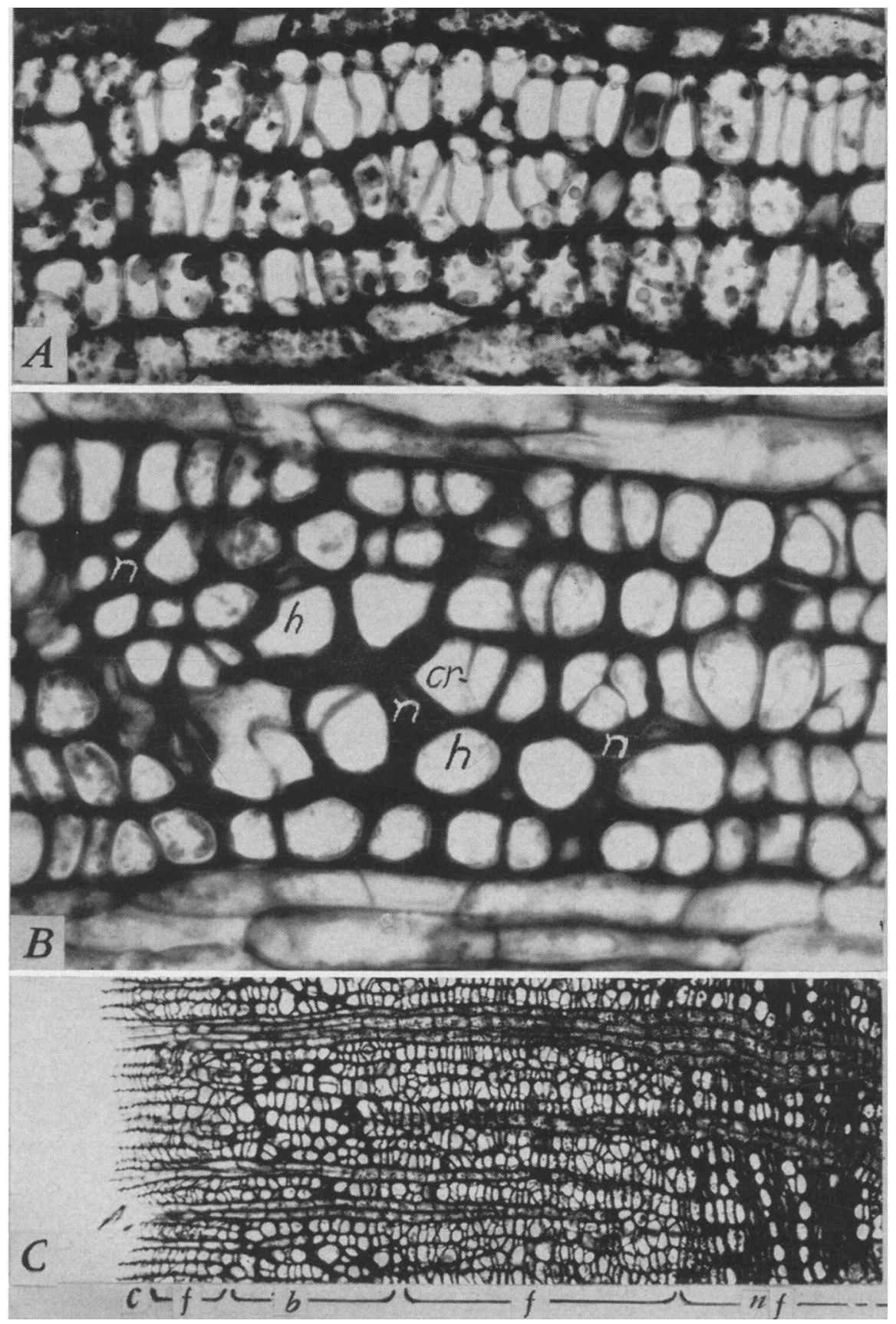

Fig. 2. Cross sections of trunk phloem of quick-decline-affected sweet orange trees on sour orange rootstock. $A, 3 / 8$ inch above bud union: sieve tubes (clear cells with small adjoining companion cells) normal. $B, 3 / 8$ inch below bud union: sieve tubes and companion cells necrotic $(n)$ and crushed between hypertrophied $(h)$ parenchyma cells, several of which have formed cross walls $(c r) . C, 1$ inch below bud union: sieve tubes and companion cells necrotic in a band $(b)$ through functioning phloem $(f)$; normal functioning phloem $(f)$ adjacent to the cambium was probably produced after necrosis occurred; nonfunctioning phloem $(n f)$ is shown at extreme right; cambium $(c)$ at left. $(A, B, \times 550$; $C, \times 120$.) 
the bud union was the first anatomical change observed (fig. 1, $A$ ). The same symptom was recognized in a lesser amount 1 inch below the union (fig. 2, $B, C)$ and was absent or only occasionally present 18 inches below the union.

The process of necrosis of sieve tubes is similar to normal degeneration: callus appears on the sieve plates, and the sieve-tube elements lose their turgidity and collapse. Hypertrophy of adjacent parenchyma cells may accompany sieve-tube necrosis and result in crushing of necrotic sieve tubes (fig. $2, B)$. It is typical for the first and most severe injury to occur near the cambium, where hypertrophy of the parenchyma is most pronounced. Ray cells are not affected in the early stages of the disease.

Anatomical Changes Subsequent to Initial Sieve-Tube Necrosis. After the initial necrosis of the sieve tubes immediately below the bud union, reactions occur in the vicinity of the bud union. Immediately above the bud union the older sieve tubes of the scion begin to degenerate (figs. $1, B ; 3, A$ ). Callus appears on the sieve plates, and the sieve tubes lose their turgidity and collapse, with little or no hypertrophy of adjacent parenchyma cells. Sieve-tube degeneration progresses upward from the bud union. While sieve-plate callus is forming above the union, necrotic changes below the union have proceeded farther, the callus is removed from sieve plates of necrotic sieve tubes, and fat globules are gradually cleared from the parenchyma cells.

One of the most striking aftereffects of sieve-tube necrosis is the stimulation of cambial activity in the vicinity of the bud union. An excessive amount of phloem is produced, in which the cells do not attain normal size (figs. $1, C$, $D ; 3, B)$. If initial necrosis occurs during the growing season, when the cambium is active, accelerated cambial activity immediately follows necrosis of the sour orange sieve tubes. If initial necrosis occurs in the winter, intensified cambial activity is delayed several months until cambial awakening in the spring. The sour orange sieve tubes in this new hyperplastic phloem sooner or later become necrotic, and the processes secondary to the necrosis described above repeat themselves in the new phloem tissues (fig. 1, $C, D$ ). The hyperplastic phloem tissues in the immediate vicinity of the bud union differ from normal: fibers usually do not develop therein; the ray cell initials derived from the cambium may fail to elongate radially to a normal degree; and heavily staining vacuolar material occurs in some parenchyma cells in the new phloem directly above the bud union (fig. $3, B$ ).

Acropetal to the hyperplastic phloem that generally forms, there is usually a band of normal phloem (fig. $3, A$ ). Below the bud union the rays occasionally become hyperplastic (fig. $4, A$ ). Cells of the hyperplastic rays may develop secondary walls, and the walls may become lignified. When the bark is removed, such woody hyperplastic rays may remain attached to the xylem;

Fig. 3. Radial sections of phloem of quick-decline-affected sweet orange trees on sour orange rootstock. $A, 1 / 4$ inch above bud union: (left) band of functioning phloem $(f)$ with normal-sized cells; (right) area in which sieve tubes apparently were induced to degenerate $(i d)$ as a result of an initial necrosis below the union; callus $(c a)$ was still present on the sieve plates. $B$, immediately above bud union: excessive amount of phloem with undersized cells, some cells filled with heavily staining material $(p) . C, 1 / 4$ inch below bud union: cells of normal size but only a few functioning sieve tubes $(f)$ near cambium $(c)$; in the area on the right $(n)$, older sieve tubes and companion cells were necrotic. $($ All $\times 260$. $)$ 

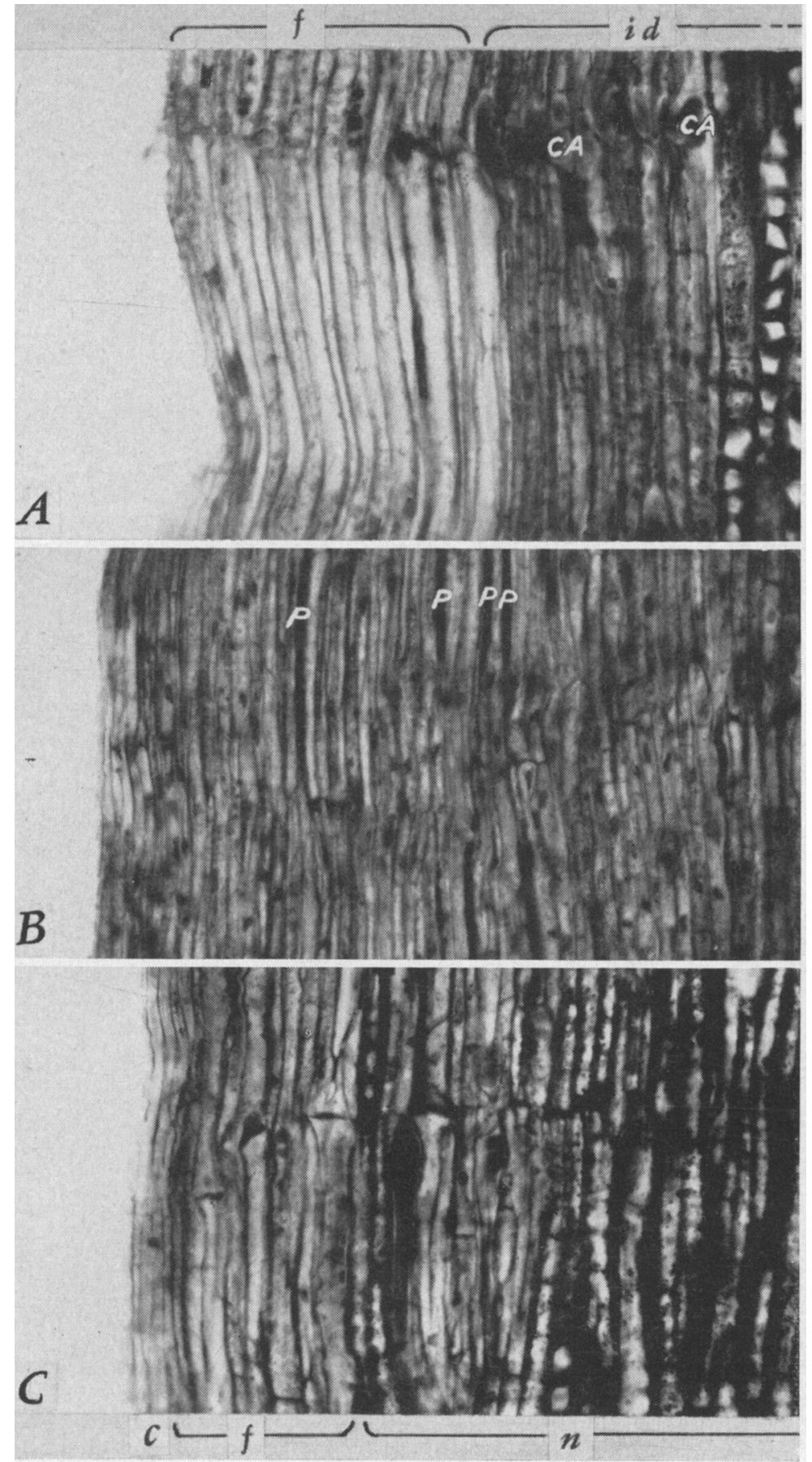


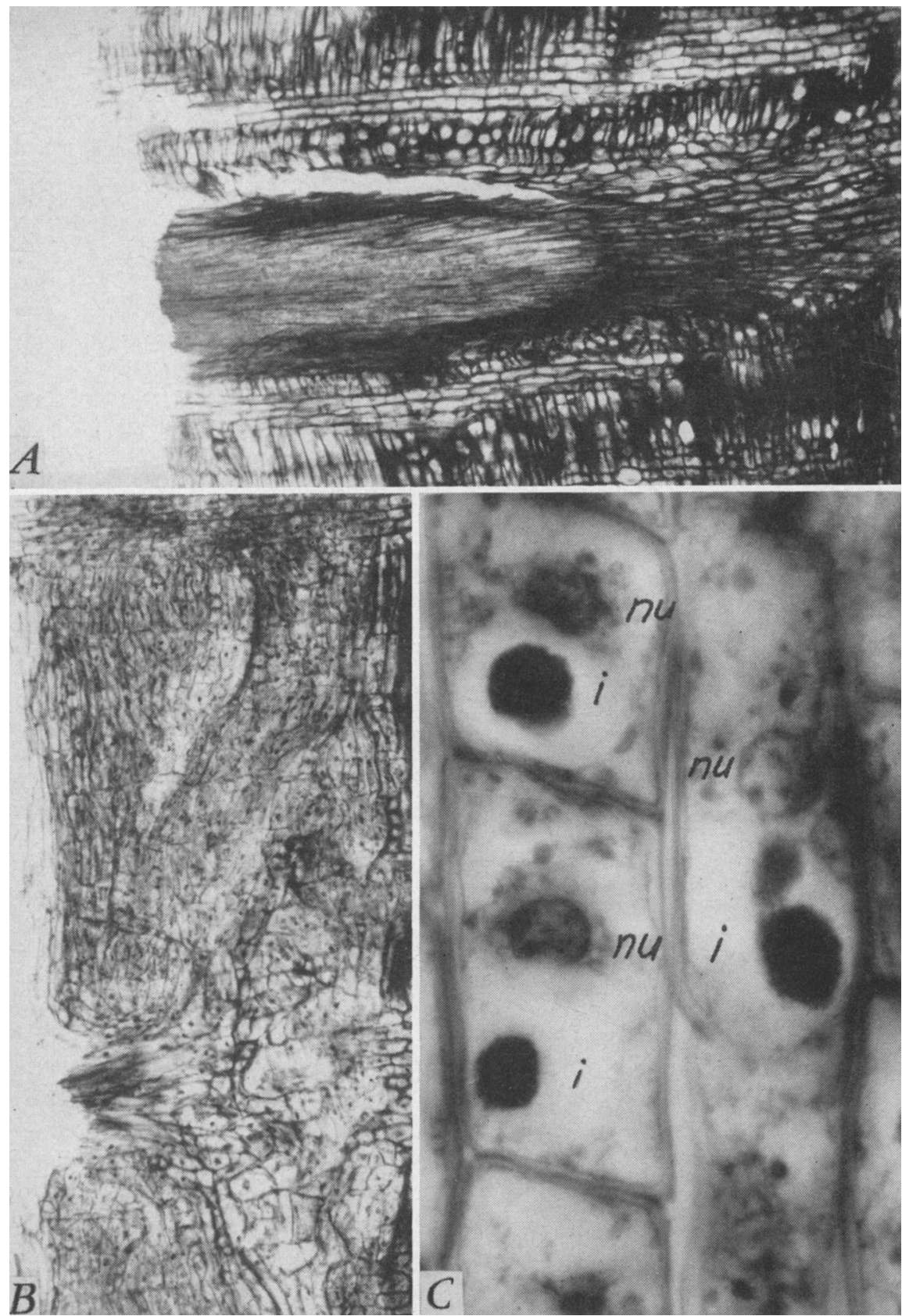

Fig. 4. Phloem of quick-decline-affected sweet orange tree on sour orange rootstock. ' $A$, radial section of hyperplastic lignified ray from below bud union (cambium at left). $B$, radial section of callus tissue formed above bud union by division of ray and parenchyma cells (cambium at left), $C$, inclusion bodies $(i)$ and nucleus $(n u)$ in parenchyma cells in vicinity of bud union. ( $A, B, \times 120 ; C, \times 1700$.) 
small holes therefore occur on the cambial face of the bark. Above the bud union the ray and phloem parenchyma may become hyperplastic at times to form a calluslike tissue (fig. $4, B$ ). The calluslike tissue formed in quickdecline trees sometimes becomes necrotic, takes on a brown color which is visible macroscopically, and adheres to the face of the wood just above the bud union when the bark is removed.

Inclusion bodies such as occur in virus-diseased plant tissues have been observed in ray and phloem parenchyma cells in the vicinity of the bud union (fig. $4, C$ ).

\section{PHLOEM 1 INCH AND 18 INCHES ABOVE AND BELOW THE BUD UNION}

Bud unions of the experimental trees were a few inches above the ground. Bark samples for sectioning were taken 1 inch above and 1 inch below the bud union, as well as 18 inches above the union (on the trunk or a large limb) and

TABLE 1

AVERAGE RADIAL WIDTH (IN MICRONS) OF FUNCTIONING PHLOEM IN BARK SAMPLES FROM TRUNKS AND ROOTS OF ORANGE TREES VARIOUSLY AFFECTED BY QUICK DECLINE

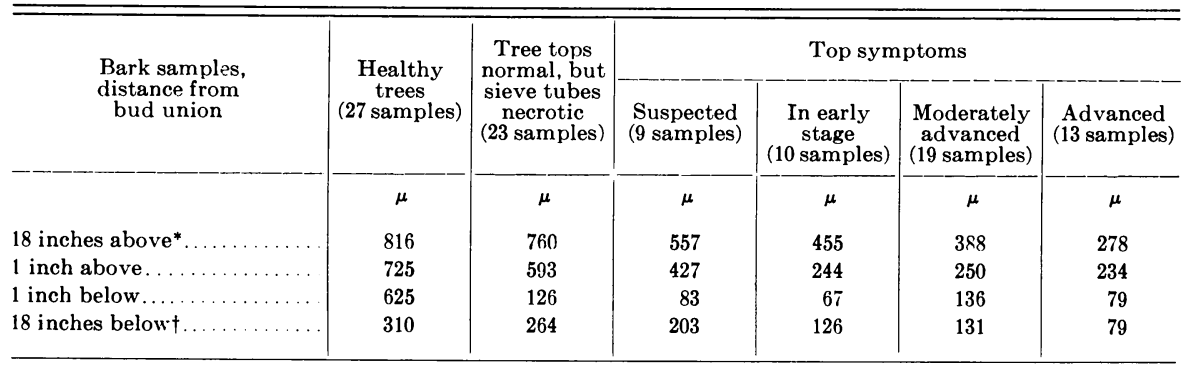

* Samples taken from trunk or large limbs.

† Samples taken from large roots.

18 inches below the union (on roots of large diameter). The radial width of the band of functioning phloem in these areas-namely, that portion of the phloem having sieve tubes which were mature but had not degenerated or become necrotic-was measured in microns. Results are presented in table 1.

The trees from which bark samples were taken may be classified as follows: (1) healthy; (2) without top symptoms of quick decline, but sieve tubes necrotic; (3) top symptoms of quick decline suspected; (4) disease in early stage (leaves gray-colored; some wilted); (5) disease in moderately advanced stage; (6) disease in advanced stage; and (7) trees in stage of equilibrium (nearly defoliated but putting out limited new dark-green growth from large branches). These categories were set up for trees that go through progressive stages of the disease until they die or reach a stage of equilibrium. Occasionally, however, trees begin to decline and then partially recuperate. The various "stages" may therefore indicate intensity of symptoms rather than the length of time the trees have been diseased. 
The most striking difference between sections of bark samples of healthy and of diseased trees was the reduction in amount of functioning phloem as a result of sieve-tube necrosis 1 inch below the bud union of diseased trees (see table 1 and fig. 5). Before the appearance of top symptoms, necrosis was usually found only for a distance of about 10 inches below the bud union, the phloem at other points of examination being affected little or not at all. At its onset, sieve-tube necrosis was frequently near the cambium (fig. 2, $C$ ).
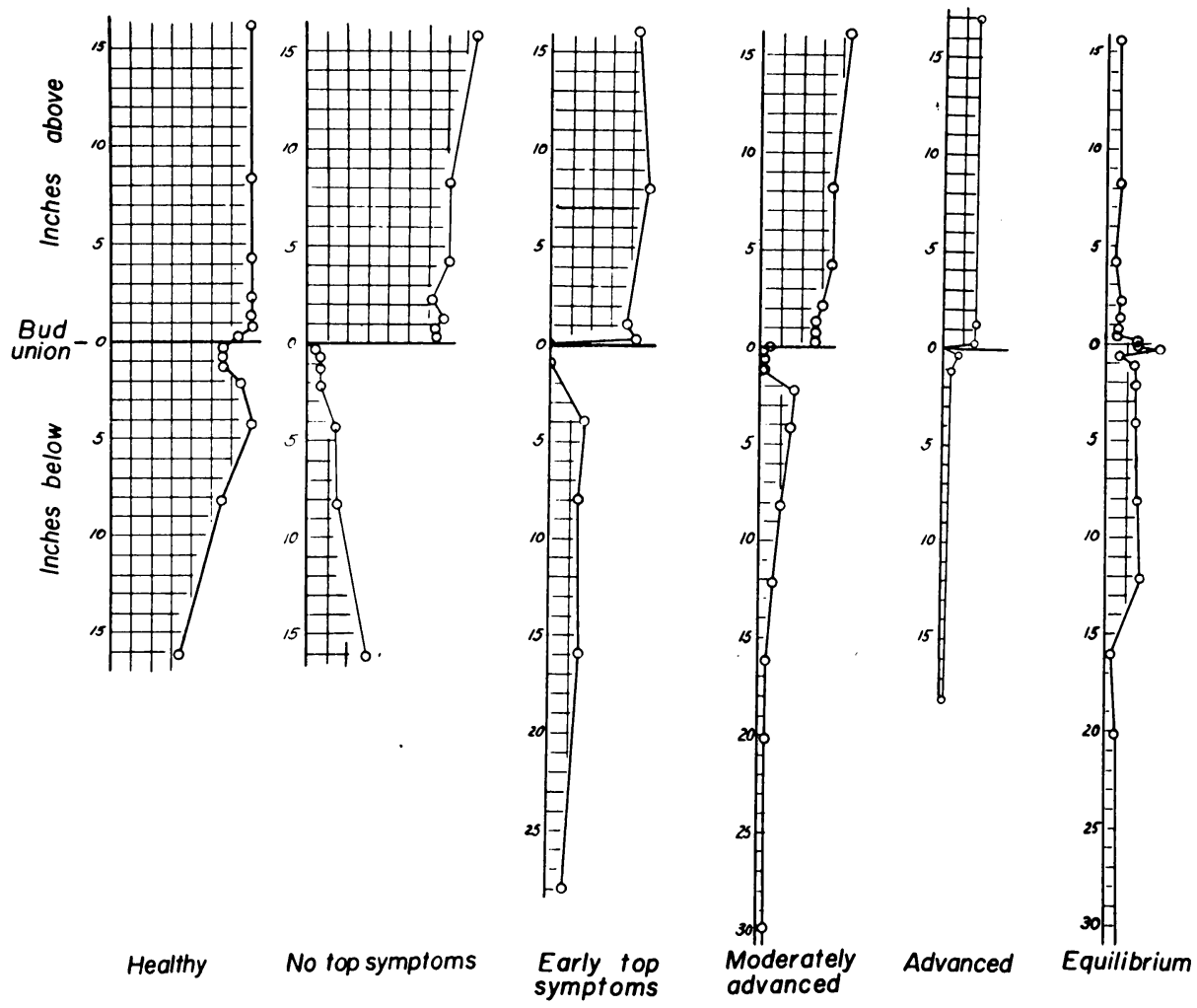

Fig. 5. Diagrams showing extent of functioning phloem (crosshatched area) in bark of a healthy sweet orange tree on sour orange rootstock, and of trees in various stages of quick decline. The vertical line at the extreme left in each diagram represents the cambium. Circles indicate locations of cross sections made for phloem measurements. Distance between vertical lines, $100 \mu$; distance between horizontal lines, 1 inch.

Necrosis of the older sieve tubes succeeded that of the younger tubes, and there was less tendency toward hypertrophy of parenchyma cells adjacent to the older tubes. At the 18-inch level below the bud union, only occasional sieve tubes became necrotic at the onset of the disease. In roots depleted of stored starch another type of sieve-tube degeneration sometimes occurred, which affected all the sieve tubes. This type of degeneration also developed in trees girdled by ringing and not affected by quick decline (Schneider, 1954b).

At an average of 12 months after the appearance of the initial anatomical symptoms, when top symptoms were just beginning to appear, the most ex- 
tensive necrosis was still found in the tissues 1 inch below the bud union, but the older sieve tubes 1 inch above the union were then beginning to degenerate. In the more advanced stages of the disease, the band of functioning phloem became narrower throughout the trunk but was narrowest in the vicinity of the bud union. The reduction in width 18 inches above the union was probably an indirect effect of tree deterioration.

\section{TIME LAG BETWEEN APPEARANCE OF SIEVE-TUBE NECROSIS AND OF TOP SYMPTOMS}

Since there is a considerable amount of reserve starch in the rootstock of orange trees, sieve-tube continuity between the top and the roots of a tree may be completely interrupted by experimental ringing or by other means for several months before any outward effects are shown by the tree (Fawcett, 1946 ; Schneider, 1954b). The incomplete girdling caused by quick decline allows an even longer period between the onset of sieve-tube necrosis and top symptoms.

Apparently healthy trees were selected at random, and phloem studies were made at various times of the year. Sieve tubes of the phloem of 38 of the trees were in an early stage of necrosis, although necrosis had been absent in some of the trees when they were sampled a few weeks earlier. The period between the beginning of necrosis and the appearance of definite decline symptoms in the tops, which were graded for symptoms and recorded at 3 -month intervals, was as long as 23 months for one tree. Where the period was extended, premature coloring of fruit was observed long before there was evidence of tree decline. The average length of time between the beginning of necrosis and the first top symptoms was $11 \frac{1 / 2}{2}$ months.

Random sampling of apparently healthy trees on different sides of the trunk at the bud union showed five trees with necrosis on one side of the trunk and not on the other. Apparently, the trees became infected on one side, and it was several months before the virus invaded the entire tree.

\section{SEASONAL VARIATION IN AMOUNTS OF FUNCTIONING AND DEVELOPING PHLOEM}

A study was made of the amount of functioning phloem immediately below the bud union of diseased trees at various times of the year. Radial measurements were made of this phloem, which was newly produced, functioned for a short time, and then became necrotic. Results of these measurements are presented graphically in figure $6, A$. Each point on the curves represents the average amount of phloem in five trees, determinations being made from one radial bud-union section per tree. The top symptoms of the trees ranged from very early stages to advanced stages of decline. The width of functioning phloem present in all the samples throughout the year ranged from 0 to $250 \mu$. The average amount of functioning phloem for all dates for both years was $70 \mu$. As stated above, the hyperplastic phloem contained cells of a size that was smaller than normal.

When phloem development is active, slime bodies are conspicuous in differentiating sieve tubes. These slime bodies are diffuse colloidal structures 
which disintegrate to form the sieve-tube slime of mature sieve tubes, and their presence appears to be the best indication of phloem formation. Curves showing the number of slime bodies present in the phloem of diseased and healthy trees at various times of the year are presented in figure $6, B$. The
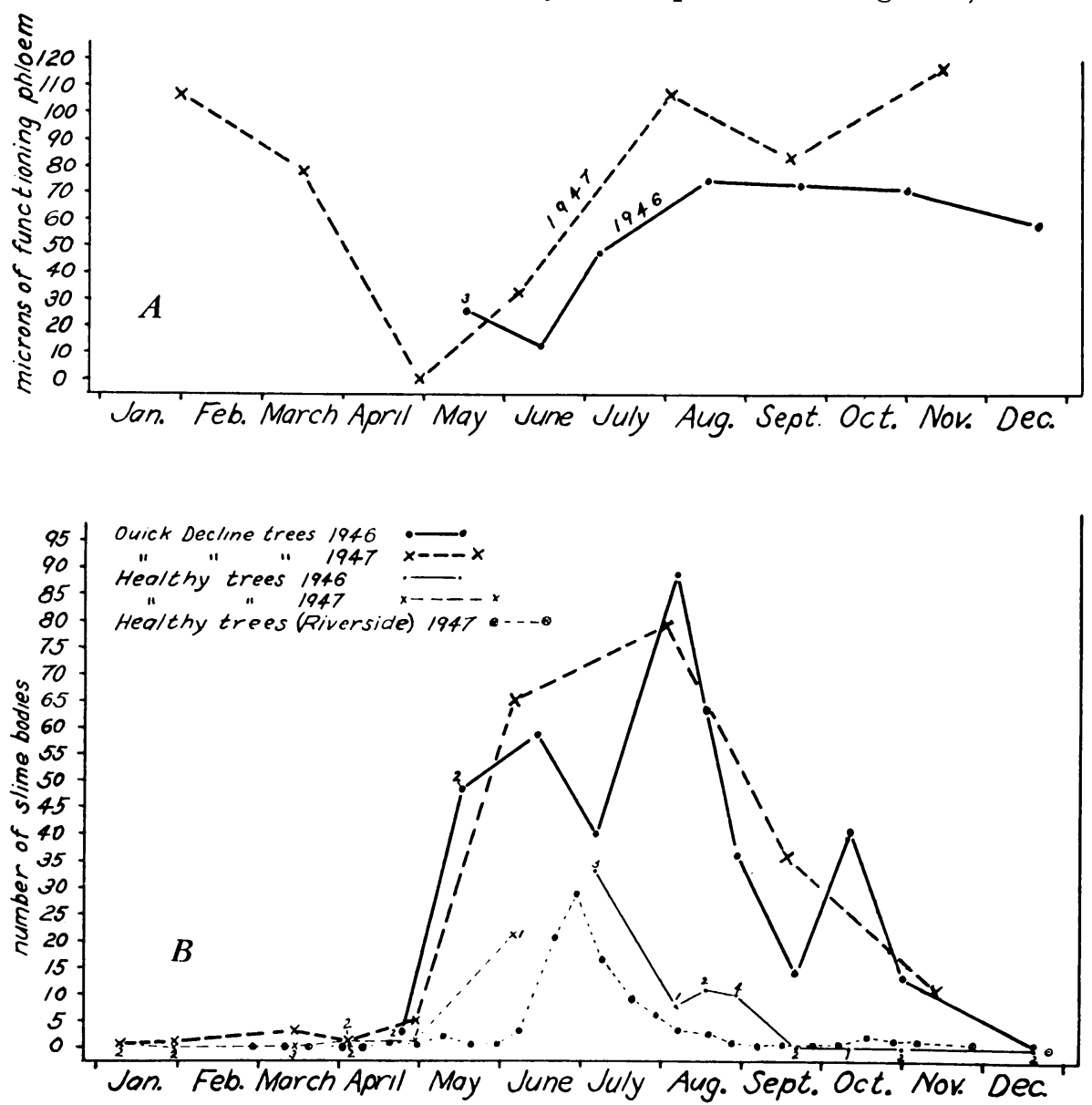

Fig. 6. $A$, average amount of functioning phloem immediately below bud union in bark samples from orange trees variously affected with quick decline, 1946 and 1947. (Each point on these curves represents average of five trees or of number of trees specified by given numeral.) $B$, total number of slime bodies per four radial sections from bark samples taken at bud unions of sweet orange trees on sour orange stock, except for healthy (control) trees at Riverside, which were sweet orange on sweet orange stock and were not sampled at bud union. (Each point on these curves represents average of six diseased trees, or of five Riverside control trees, or of number of trees specified by given numerals.)

slime bodies present in four radial sections approximately $20 \mu$ thick and $1 \mathrm{~cm}$ long were counted for each sample. The maximum number of slime bodies found in four sections from diseased trees was 178, as compared with 39 in sections from healthy trees. Both the intensity and the duration of sieve-tube production are greater in diseased trees than in healthy ones. 


\section{INCUBATION PERIOD FOR SIEVE-TUBE NECROSIS IN YOUNG SWEET ORANGE TREES ON SOUR ORANGE ROOTSTOCKS}

In an attempt to determine how long a period is required for sieve-tube necrosis to develop after inoculation, nursery-sized healthy sweet orange trees on sour orange stock were inoculated by budding. Bark sampling was begun 5 months later, and was continued at approximately 4 -week intervals. The trees used were from a transmission experiment conducted by $\mathrm{H}$. S. Fawcett and J. M. Wallace. The trees were planted in the field in November, 1945; they were inoculated in July, 1946, and sampling was begun December 3,1946 . Because the trees were small, the periodic samples could not all be taken from the same trees; some of the trees were sampled on two collecting dates, however.

On December 3, 5 months after inoculation, six inoculated trees were observed to have phloem which was in as good condition as that of the check trees. On February 10, 7 months after inoculation, two trees out of ten had developed sieve-tube necrosis below the union. On March 13 definite sievetube necrosis was present in seven trees and there was some question about three others. Of twenty trees sampled on April 28, twelve had definite necrosis and two were questionable. Definite necrosis was present on June 21, in two of ten trees (different trees were sampled on each date), and on August 6, seven of ten had definite necrosis. This indicates that it takes about 7 months or longer for sieve-tube necrosis to appear in 2- to 3-year-old trees after bud inoculation in the scaffold branches.

Detection of early necrosis in young budded trees is occasionally difficult because there are only a few sieve tubes in the band of functioning phloem of small, recently planted trees, and if half of these sieve tubes become necrotic owing to quick decline, they are hardly noticeable. Also, new phloem formed in affected trees may not become necrotic immediately. In this respect young trees differ from mature trees. In mature trees the comparatively wide band of phloem normally present in healthy trees is only partially replaced after sieve tubes become necrotic, and then with a new phloem tissue composed of small cells (fig. 3, B). One young tree showing sieve-tube necrosis in February had, in June, a normal band of functioning and developing phloem (indicated by slime bodies and new fibers without secondary walls), but by August the tree was showing top symptoms of quick decline.

\section{SUMMARY}

Anatomical disturbances in sweet orange trees on sour orange rootstock infected by the quick-decline virus were investigated. The first anatomical symptom is necrosis of sieve tubes and companion cells immediately below the bud union. The youngest sieve tubes are usually affected first. Adjacent parenchyma cells hypertrophy and may divide once or twice.

Anatomic changes in the vicinity of the bud union after the initial necrosis of sieve tubes are as follows: degeneration of the older sieve tubes and companion cells above the union; an overactivity of phloem production 
at the bud union, where phloem cells are smaller than normal; and, occasionally, the production of calluslike tissue above the union. In addition, the rays below the union may become hyperplastic, and the walls of such ray cells may become thickened and lignified. Inclusion bodies are sometimes present in parenchyma cells at the bud union.

One fourth of an inch above the union there is usually a band of normal, functioning phloem, which, however, is narrower than in healthy trees. Immediately below the union a much narrower band of functioning phloem composed of small cells is usually found. One fourth of an inch below the union there may be a few sieve tubes of normal size adjacent to the cambium.

Farther from the bud union ( 1 inch or more above), the phloem remains normal until the tree begins to deteriorate.

Eighteen inches below the bud union, in the roots, necrosis of sieve tubes and hypertrophy of parenchyma occasionally occur. As the starch becomes depleted in the roots, degeneration of sieve tubes at times becomes general. A similar condition has been found in trees artificially ringed.

The width of the functioning phloem immediately below the bud union of trees showing decline symptoms ranged from 0 to $250 \mu$ (average width, $70 \mu$ ).

Some functioning sieve tubes immediately below the bud union were present in most of the trees throughout the year, except for a short period in the spring when phloem formation was beginning and necrosis was almost complete.

Phloem production at the bud union was more intense in diseased trees than in healthy trees and it continued over a longer period.

Necrosis appeared in 2- to 3-year-old orange trees about 7 months after inoculation by budding.

\section{ACKNOWLEDGMENTS}

The author is indebted to Drs. H. S. Fawcett and J. M. Wallace for the use of bark samples from their experimental trees ; to Messrs. Oscar F. Clarke and L. C. Masters for preparing sections ; and to Drs. Katherine Esau, F. Murray Scott, L. J. Klotz, J. M. Wallace, and B. E. Day for reading the manuscript and making helpful suggestions.

\section{LITERATURE CITED}

Altstatt, George E., R. L. McClain, and Gilbert L. Stout

1948. A second report on state-wide surveys for quick decline of orange trees in California. California Dept. Agr. Bul. 37: 168-75.

ARTSChWAGER, ERNST F.

1923. Occurrence and significance of phloem necrosis in the Irish potato. Jour. Agr. Res. 24 : 237-46.

Batchelor, Leon Dexter, and Herbert John Webber (Eds.)

1948. The citrus industry, Vol. II. Production of the crop. $x v+933$ p. University of California Press, Berkeley and Los Angeles.

Bennetr, C. W., and A. S. Costa

1949. Tristeza disease of citrus. Jour. Agr. Res. 78: 207-37.

Cheadle, Vernon I., Ernest M. Gifford, Jr., and Katherine Esau

1953. A staining combination for phloem and contiguous tissues. Stain Technol. 28: 49-53. 
Dickson, R. C., R. A. Flock, and M. MCD. Johnson

1951. Insect transmission of citrus quick-decline virus. Jour. Econ. Ent. 44 : 172-76.

FAWCETT, H. S.

1945. A starch test for quick decline. California Citrog. $30: 122$.

1946. A progress report on quick decline studies. Introduction (Part I). California Citrog. 31: 198.

FAWCETT, H. S., and J. M. WAllace

1946. Evidence of the virus nature of citrus quick decline. California Citrog. 32: 50, 88-89. Also in: Citrus Leaves 26(12) : 9-10.

Halma, F. F., K. M. Smoyer, and H. W. Schwalm

1945. Rootstock in relation to quick decline of citrus. California Citrog. 30: 150-51.

McAlpin, D. M., P. S. Parsai, R. Roberts, and R. H. Hope

1948. "Bud-union decline" disease in citrus trees. Victoria Dept. Agr. Jour. 46: 25-31.

SCHNEIDER, HENRY

1945. Anatomy of buckskin-diseased peach and cherry. Phytopathology 35: 610-35.

1946. A progress report on quick decline studies. Histological studies (Part III). California Citrog. 31: 198-99.

1947. Sieve-tube necrosis in orange trees affected by quick decline during the spring season. Phytopathology $37: 364$.

1952. The phloem of the sweet orange tree trunk and the seasonal production of xylem and phloem. Hilgardia 21: 331-66.

1954a. Condition of phloem of sour orange tree trunk in winter. Hilgardia 22(16): 583-91.

1954b. Effect of trunk girdling on phloem of trunk of sweet orange trees on sour orange rootstock. Hilgardia 22(16) : 593-601.

Schneider, Henry, A. A. Bitancourt, and Victoria Rossetti

1947. Similarities in the pathological anatomy of quick-decline and Tristeza-diseased orange trees. Phytopathology 37: 845-46.

Schneider, Henry, J. M. Wallace, and J. E. Dimitman

1950. The pathological anatomy of bud-union tissues of orange trees and its value in the diagnosis of quick decline. Phytopathology 40: 24 .

SCHUMACHER, WALTER

1930. Untersuchungen über die Localisation der Stoffwanderung in den Leitbündeln höherer Pflanzen. Jahrb. f. Wiss. Bot. 73: 770-823.

WALLACE, J. M.

1951. Recent developments in studies of quick decline and related diseases. Phytopathology 41: 785-93. 


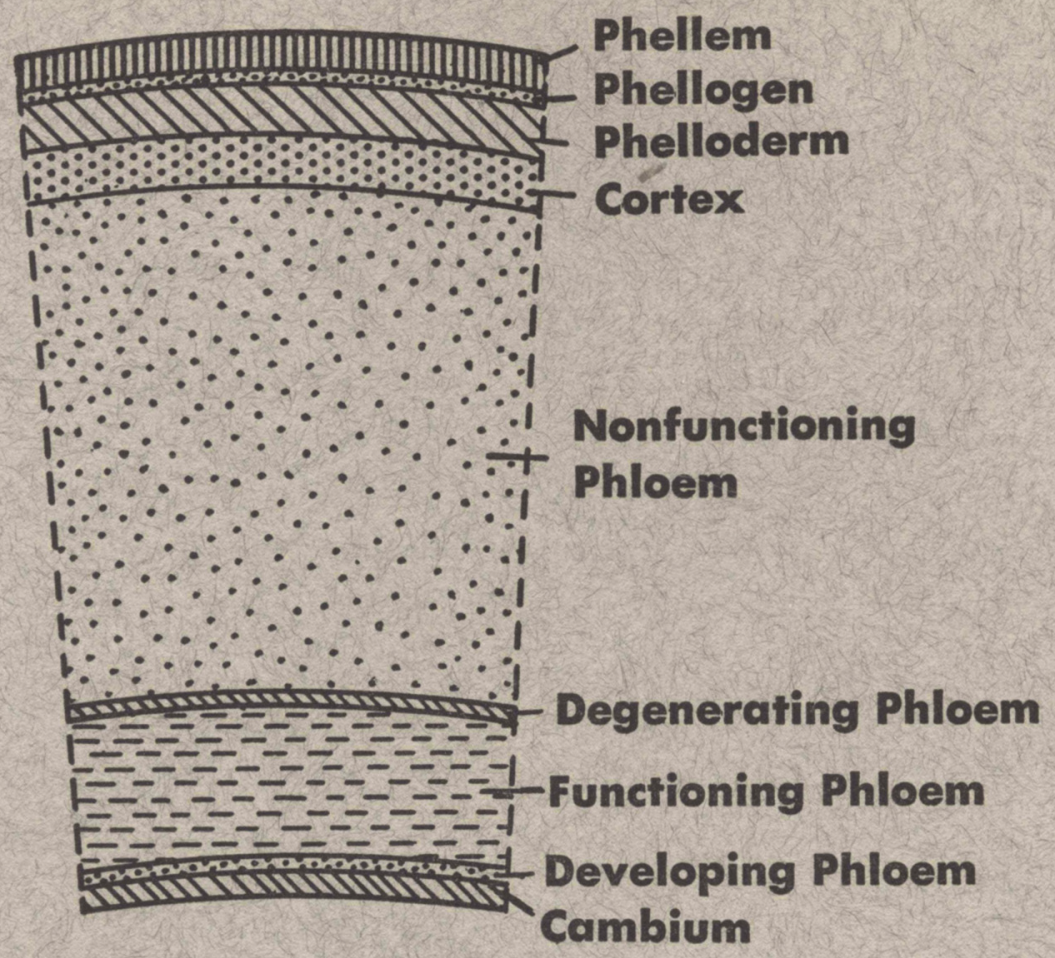

The normal phloem of the orange tree trunk is a complex tissue. Its vertical system consists of sieve tubes, companion cells, parenchyma cells, fibers, and crystal idioblasts. The four zones of the phloem may be described as follows: (1) the developing phloem is the ring of phloem adjacent to the cambium, in which cells derived from the cambium divide further and then differentiate into mature phloem tissue. (2) The functioning phloem is the ring of phloem located just outside the developing phloem and containing mature sieve tubes. (3) The degenerating phloem is the ring of phloem located at the outer margin of the functioning phloem. In this tissue the sieve plates of the sieve tubes become callused, the sieve tubes lose their turgor and then collapse, and the contents are lysed. Some parenchyma cells also degenerate, lose their contents, and are crushed. (4) The vertical system of the nonfunctioning phloem contains blocks of degenerated sieve tubes and living and dead parenchyma cells. 
The journal Hilgardia is published at irregular intervals, in volumes of about 600 pages. The number of issues per volume varies.

Subscriptions are not sold. The periodical is sent as published only to libraries, or to institutions in foreign countries having publications to offer in exchange.

You may obtain a single copy of any issue free, as long as the supply lasts; please request by volume and issue number from:

\section{Publications Office \\ College of Agriculture \\ Berkeley 4, California}

The limit to nonresidents of California is 10 separate issues on a single order. A list of the issues still available will be sent on request. 